\title{
Relevant Advanced Reactor Benchmarks for Nuclear Data Assessment
}

Approved for public release. Distribution is unlimited.
Friederike Bostelmann Erik D. Walker Steve E. Skutnik Germina Ilas William A. Wieselquist

September 2020 


\title{
DOCUMENT AVAILABILITY
}

Reports produced after January 1, 1996, are generally available free via US Department of Energy (DOE) SciTech Connect.

Website www.osti.gov

Reports produced before January 1,1996, may be purchased by members of the public from the following source:

\author{
National Technical Information Service \\ 5285 Port Royal Road \\ Springfield, VA 22161 \\ Telephone 703-605-6000 (1-800-553-6847) \\ TDD 703-487-4639 \\ Fax 703-605-6900 \\ E-mail info@ntis.gov \\ Website http://classic.ntis.gov/
}

Reports are available to DOE employees, DOE contractors, Energy Technology Data Exchange representatives, and International Nuclear Information System representatives from the following source:

Office of Scientific and Technical Information

PO Box 62

Oak Ridge, TN 37831

Telephone 865-576-8401

Fax 865-576-5728

E-mail reports@osti.gov

Website http://www.osti.gov/contact.html

This report was prepared as an account of work sponsored by an agency of the United States Government. Neither the United States Government nor any agency thereof, nor any of their employees, makes any warranty, express or implied, or assumes any legal liability or responsibility for the accuracy, completeness, or usefulness of any information, apparatus, product, or process disclosed, or represents that its use would not infringe privately owned rights. Reference herein to any specific commercial product, process, or service by trade name, trademark, manufacturer, or otherwise, does not necessarily constitute or imply its endorsement, recommendation, or favoring by the United States Government or any agency thereof. The views and opinions of authors expressed herein do not necessarily state or reflect those of the United States Government or any agency thereof. 
Reactor and Nuclear Systems Division

\title{
RELEVANT ADVANCED REACTOR BENCHMARKS FOR NUCLEAR DATA ASSESSMENT
}

Friederike Bostelmann, Erik D. Walker, Steve E. Skutnik, Germina Ilas, William A. Wieselquist

Date Published: September 2020

\author{
Prepared by \\ OAK RIDGE NATIONAL LABORATORY \\ Oak Ridge, TN 37831-6283 \\ managed by \\ UT-BATTELLE, LLC \\ for the \\ US DEPARTMENT OF ENERGY \\ under contract DE-AC05-00OR22725
}





\section{CONTENTS}

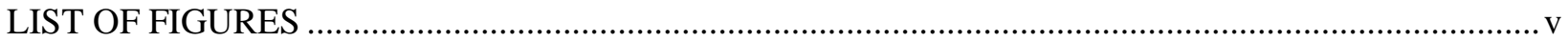

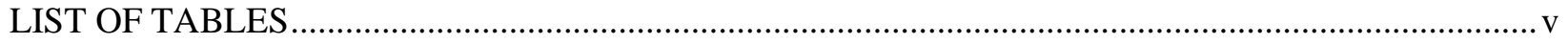

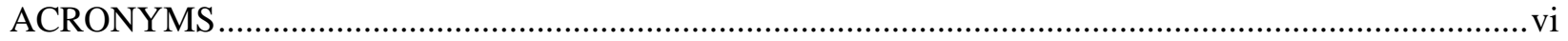

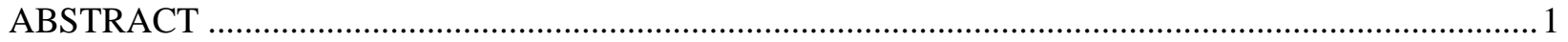

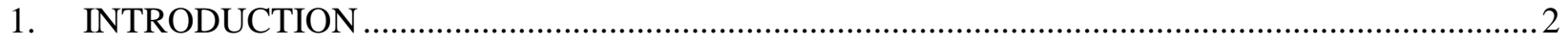

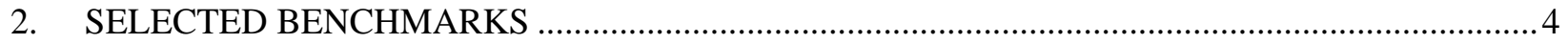

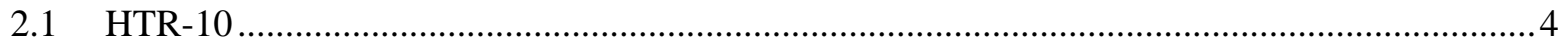

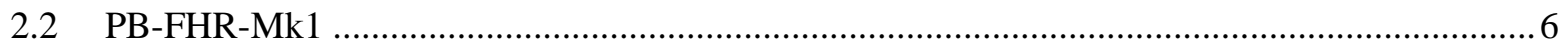

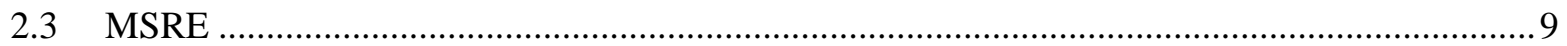

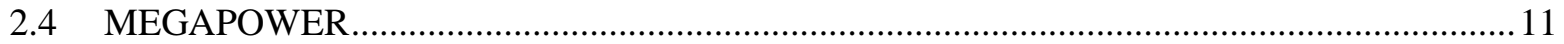

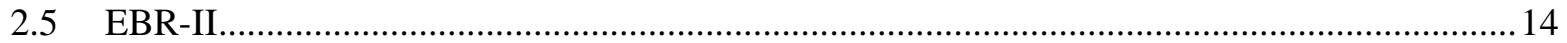

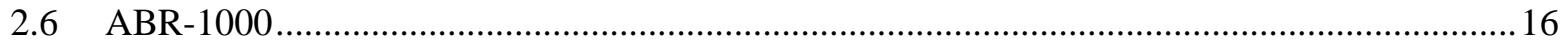

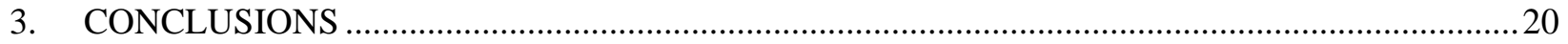

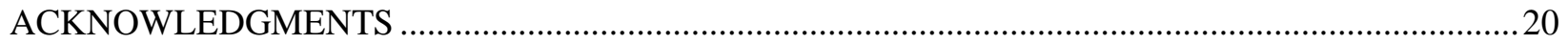

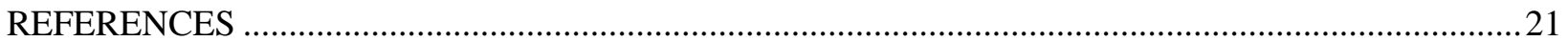





\section{LIST OF FIGURES}

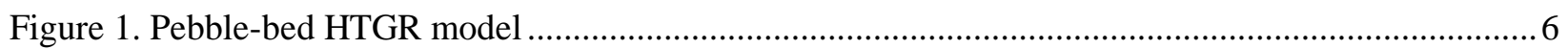

Figure 2. Representative TRISO fuel particle and pebble model as included in the HTR-10...................6

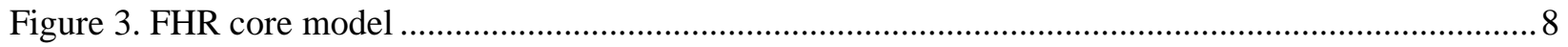

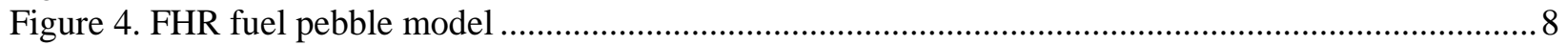

Figure 5. Horizontal cross section of the MSRE benchmark …....................................................... 10

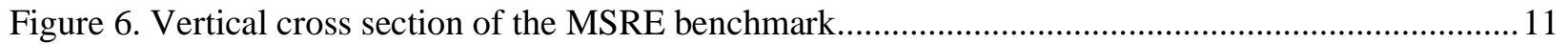

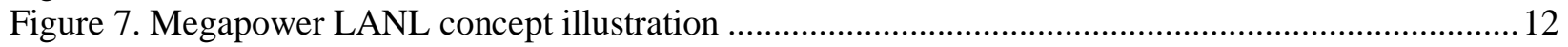

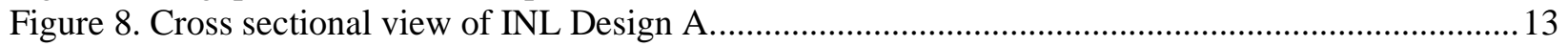

Figure 9. Material composition and dimensions for a INL Design A heat pipe fuel element.................... 13

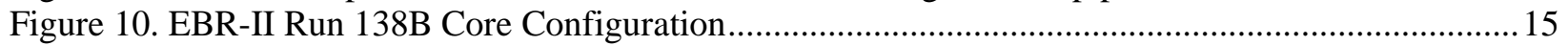

Figure 11. EBR-II driver rod (left) and assembly (right) ................................................................... 16

Figure 12. Sodium-cooled fast reactor model cross section view ........................................................ 18

Figure 13. Fuel assembly model of a sodium-cooled fast reactor .......................................................... 19

\section{LIST OF TABLES}

Table 1. Overview of selected advanced reactor technologies............................................................ 3

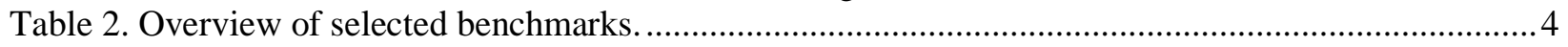

Table 3. Key characteristics of the initial critical configuration of the HTR-10 ......................................5

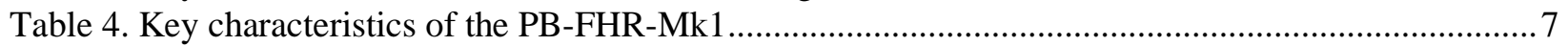

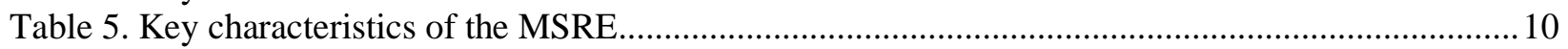

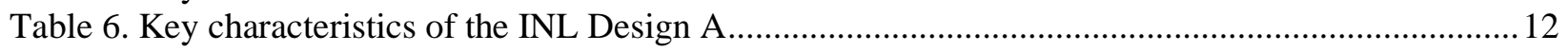

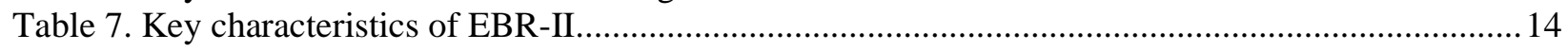

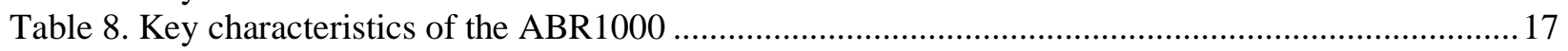




\section{ACRONYMS}

$\begin{array}{ll}\text { ABR } & \text { Advanced Burner Reactor } \\ \text { EBR-II } & \text { Experimental Breeder Reactor II } \\ \text { FHR } & \text { fluoride-salt-cooled high-temperature reactor } \\ \text { HTGR } & \text { high-temperature gas-cooled reactor } \\ \text { ICSBEP } & \text { International Criticality Safety Benchmark Evaluation Project } \\ \text { INL } & \text { Idaho National Laboratory } \\ \text { IRPhEP } & \text { International Reactor Physics Experiment Evaluation Project } \\ \text { LANL } & \text { Los Alamos National Laboratory } \\ \text { LEU } & \text { low-enriched uranium } \\ \text { LWR } & \text { light water reactor } \\ \text { MCNP } & \text { Monte Carlo N-Particle } \\ \text { MSR } & \text { molten salt reactor } \\ \text { MSRE } & \text { Molten Salt Reactor Experiment } \\ \text { MW } & \text { megawatt } \\ \text { NRC } & \text { US Nuclear Regulatory Commission } \\ \text { OECD/NEA } & \text { Organisation for Economic Co-operation and Development / Nuclear Energy Agency } \\ \text { ORNL } & \text { Oak Ridge National Laboratory } \\ \text { PyC } & \text { pyrolytic carbon } \\ \text { SFR } & \text { sodium-cooled fast reactor } \\ \text { SiC } & \text { silicon carbide } \\ \text { TRISO } & \text { tristructural isotropic }\end{array}$




\begin{abstract}
Advanced reactor concepts currently being developed throughout the industry are significantly different from light water reactor (LWR) designs with respect to geometry, materials, and operating conditions, and consequently, with respect to their reactor physics behavior. Given the limited operating experience with non-LWRs, the accurate simulation of reactor physics and the quantification of associated uncertainties are critical for ensuring that advanced reactor concepts operate within the appropriate safety margins.

Nuclear data are a major source of input uncertainties in reactor physics analysis. As part of an ongoing project at Oak Ridge National Laboratory, the effects of nuclear data uncertainties on key figures of merit associated with advanced reactor safety are being assessed for selected advanced reactor technologies.

Key nuclear data relevant for reactor safety analysis for each selected advanced reactor technology were identified in Phase 1, and their impact on important key figures of merit was assessed in Phase 2.

This report describes the outcome of Phase 3. Available benchmarks and fuel irradiation data for use in evaluating the impact of uncertainties and gaps in nuclear data that impact reactivity control for advanced reactor designs through the fuel cycle were identified and assessed. Benchmarks were identified by searching (1) the Organisation for Economic Co-operation and Development (OECD)/Nuclear Energy Agency (NEA) International Criticality Safety Benchmark Evaluation Project (IRPhEP) handbook, (2) the OCED/NEA International Reactor Physics Experiment Evaluation Project (IRPhEP) handbook, (3) ongoing OECD/NEA benchmark activities, and (4) documentation in public literature. Relevant benchmarks were identified by selecting reactors with geometry, materials, and neutron energy spectra similar to those of selected advanced reactor technologies. This assessment identified six benchmarks, of which three are experimental and three are purely computational. One experimental and one computation benchmark contain depleted fuel; all others are limited to fresh fuel. This report provides short descriptions of the selected benchmarks along with the availability of measured data for comparison.
\end{abstract}




\section{INTRODUCTION}

Uncertainty analyses are an essential component in the design and analysis of advanced reactors, especially due to the growing interest in new reactor concepts that differ significantly from the designs for traditional light water reactors (LWRs). The advanced reactor concepts currently being developed throughout the industry are significantly different from LWR designs with respect to geometry, materials, and operating conditions, and consequently, with respect to their reactor physics behavior. Given the limited operating experience with non-LWRs, the accurate simulation of reactor physics and the quantification of associated uncertainties are critical for ensuring that advanced reactor concepts operate within the appropriate safety margins.

Nuclear data are a major source of input uncertainties in reactor physics analyses since they provide the basis for every reactor physics calculation. The nuclear interaction cross sections, fission yields, and decay data used in these calculations have uncertainty from measurements and from the data evaluations subsequent to the measurements. To better understand uncertainties in the calculation of safety-relevant output quantities due to nuclear data and to decide where additional efforts should focus to reduce relevant nuclear data uncertainties, these data need to be propagated to key figures of merit impacting nuclear safety.

As part of the ongoing project, Nuclear Data Assessment for Advanced Reactors, which is funded by the US Nuclear Regulatory Commission (NRC), the impact of nuclear data uncertainties on key figures of merit associated with advanced reactor safety is assessed for selected advanced reactor technologies. The project includes four phases:

- Phase 1: Identify key nuclear data impacting reactivity in non-LWRs,

- Phase 2: Assess key nuclear data impacting reactivity in non-LWRs,

- Phase 3: Assess relevant benchmarks applicable to the nuclear data identified in Phases 1 and 2, and

- Phase 4: Assess the impact of nuclear data uncertainty through propagation to key figures of merit associated with reactor safety.

Phases 1 and 2 were concluded, and the outcome has been published (Bostelmann et al., 2020a). This report summarizes the findings of Phase 3. For each of the relevant advanced reactor technologies (listed in Table 1), available benchmarks resources were identified and reviewed to select benchmarks applicable for assessing the impact of uncertainties and gaps in nuclear data on the figures of merit of interest in Phase 4.

Applicable benchmarks were found in the Organisation for Economic Co-operation and Development (OECD) / Nuclear Energy Agency (NEA) International Criticality Safety Benchmark Evaluation Project (ICSBEP) handbook and the International Reactor Physics Experiment Evaluation Project (IRPhEP) handbook. The ICSBEP handbook includes criticality safety benchmark specifications with a wide range of fissile materials, physical forms of fissile materials, and neutron spectra. The IRPhEP handbook contains specifications of a large number of experiments with various reported output quantities such as reactivity effects and power distributions. Other benchmarks were found in ongoing NEA benchmark activities for uncertainty analysis in modeling and in the open literature.

Given the limited availability of measured data for advanced reactor systems, for some reactor technologies only theoretical or simplified descriptions were found. However, as long as the models 
include representative geometric dimensions and representative materials, uncertainty analyses of these models can still be used to understand the impact of nuclear data uncertainties and to identify relevant nuclide reactions.

The following steps were included in Phase 3.

- Investigated various NEA databases to identify applicable benchmarks and searched for additional publicly available sources of applicable measurements.

- Identified theoretical or simplified computational models from available previous reports that are representative for the reactor technologies of interest.

- Assessed the benchmarks with respect to the reported measurements of quantities of interest, their applicability to the reactor technology of interest, as well as the corresponding modeling and computation efforts.

- Selected the benchmarks for each reactor technology of interest including the quantities of interest to be investigated for the individual cases.

The overall goal of the project is to study the following quantities of interest: (1) core reactivity, (2) the 4factor formula, (3) control rod worth, (4) temperature and expansion coefficients, (5) kinetic parameters, (6) spectral indices, and (7) power distribution, including peak pin power and peak power. The quantities' level of importance to reactor safety can differ between various advanced reactor concepts. While all these quantities were considered during the selection of benchmarks, the availability of measured quantities for comparison with calculated results was found to be very limited for the advanced reactor technologies of interest.

Section 2 briefly describes the selected benchmarks for consideration in the analysis work of Phase 4 and provides an overview of the corresponding available measured quantities.

Table 1. Overview of selected advanced reactor technologies

\begin{tabular}{|c|c|c|c|c|}
\hline Reactor type & Reactor technology & Fuel & Moderator & Coolant \\
\hline $\begin{array}{l}\text { Thermal spectrum, high- } \\
\text { temperature gas-cooled } \\
\text { reactor (HTGR) }\end{array}$ & Pebble-bed HTGR & $\mathrm{UCO}$ or $\mathrm{UO}_{2}$ & Graphite & Helium \\
\hline $\begin{array}{l}\text { Thermal spectrum, molten } \\
\text { salt reactor (MSR) }\end{array}$ & $\begin{array}{l}\text { Fluoride-salt-cooled high- } \\
\text { temperature reactor } \\
\text { (FHR) }\end{array}$ & $\mathrm{UCO}$ or $\mathrm{UO}_{2}$ & Graphite & FLiBe \\
\hline Thermal spectrum MSR & Graphite-moderated MSR & $\mathrm{LiF}-\mathrm{BeF}_{2}-\mathrm{UF}_{4}$ & Graphite & $\begin{array}{l}\text { Fuel serves as } \\
\text { coolant }\end{array}$ \\
\hline $\begin{array}{l}\text { Fast spectrum, oxide and } \\
\text { metal fueled, stationary } \\
\text { microreactor }\end{array}$ & Heat pipe reactor & $\begin{array}{l}\mathrm{UO}_{2}, \mathrm{UN} \\
\text { or U-10Zr }\end{array}$ & -- & Potassium, sodium \\
\hline $\begin{array}{l}\text { Fast spectrum, metal and } \\
\text { oxide fueled, sodium-cooled } \\
\text { reactor }\end{array}$ & $\begin{array}{l}\text { Sodium-cooled fast } \\
\text { reactor (SFR) }\end{array}$ & $\begin{array}{l}\text { U/TRU-Zr or } \\
\text { U/TRU oxide }\end{array}$ & -- & Sodium \\
\hline
\end{tabular}




\section{SELECTED BENCHMARKS}

For the advanced reactor technologies selected for consideration in this project, representative benchmarks were selected for further analysis in Phase 4. In this section, the selected reactor concepts are briefly described with respect to their basic geometrical features, relevant included materials, and temperatures. Table 2 provides an overview of the selected benchmarks.

Table 2. Overview of selected benchmarks.

\begin{tabular}{llll}
\hline Reactor type & Reactor technology & Selected benchmark & Type \\
\hline $\begin{array}{l}\text { Thermal spectrum, high- } \\
\text { temperature gas-cooled } \\
\text { reactor (HTGR) }\end{array}$ & Pebble-bed HTGR & HTR-10 (Terry et al., 2007) & Experiment \\
\hline $\begin{array}{l}\text { Thermal spectrum, molten } \\
\text { salt reactor (MSR) }\end{array}$ & $\begin{array}{l}\text { Fluoride-salt-cooled } \\
\text { high-temperature } \\
\text { reactor (FHR) }\end{array}$ & $\begin{array}{l}\text { UC Berkeley Mark1 (Mk1) PB- } \\
\text { FHR (Andreades et al., 2014) }\end{array}$ & Computational benchmark \\
\hline $\begin{array}{l}\text { Traphite-moderated } \\
\text { MSR }\end{array}$ & MSRE (Shen et al., 2019) & Experiment \\
\hline $\begin{array}{l}\text { Fast spectrum, oxide and } \\
\text { metal fueled, stationary } \\
\text { microreactor }\end{array}$ & Heat pipe reactor & $\begin{array}{l}\text { LANL Megapower Design A } \\
\text { (Sterbentz et al., 2018) }\end{array}$ & Computational benchmark \\
\hline $\begin{array}{l}\text { Fast spectrum, metal } \\
\text { fueled, sodium-cooled } \\
\text { reactor }\end{array}$ & $\begin{array}{l}\text { Sodium-cooled fast } \\
\text { reactor (SFR) }\end{array}$ & $\begin{array}{l}\text { EBR-II (Lum et al., 2018), } \\
\text { ABR1000 (Buiron et al., 2019) }\end{array}$ & $\begin{array}{l}\text { Experiment, } \\
\text { Computational benchmark }\end{array}$ \\
\hline
\end{tabular}

\section{$2.1 \quad$ HTR-10}

The benchmark selected for the pebble-bed high-temperature gas-cooled reactor (HTGR) technology is the small 10 MWth prototype pebble-bed reactor HTR-10, operated at Tsinghua University in China. With a core diameter of $1.8 \mathrm{~m}$ and a mean height of $1.97 \mathrm{~m}$, it contains almost 10,000 fuel pebbles surrounded by graphite reflector structures (Figure 1). This reactor was designed to help in the development of pebble-bed technology in China and to test fuel, safety features, operational behavior, and other factors. Construction began in 1995, first criticality was achieved in December 2000, and the reactor operated at full power condition through January 2003.

The IRPhEP handbook contains high-fidelity specifications of the initial critical configuration (Terry et al., 2007). For this configuration, the conus and discharge tube were filled with pure graphite "dummy" pebbles. The key characteristics of the HTR-10 are presented in Table 3.

The cylindrical core consisted of a mixture of 9,627 fuel pebbles and 7,263 dummy pebbles at a packing fraction of $61 \%$. Criticality was achieved at room temperature while all control rods in the outer graphite reflector were withdrawn. Instead of including helium coolant, void spaces were filled with ambient air.

The fuel pebble consisted of a fuel zone $5 \mathrm{~cm}$ in diameter that contained over 8,000 tristructural isotropic (TRISO) fuel particles distributed randomly in a graphite matrix, surrounded by a $5 \mathrm{~mm}$ graphite layer, resulting in a pebble with a $6 \mathrm{~cm}$ outer diameter (Figure 2). A TRISO fuel particle was $0.91 \mathrm{~mm}$ in diameter and includes a micro fuel kernel $0.5 \mathrm{~mm}$ in diameter composed of uranium oxide. The fuel kernel was enclosed by four concentric coatings: a porous graphite buffer, an inner pyrolytic carbon $(\mathrm{PyC})$ layer, a ceramic silicon carbide (SiC) layer, and an outer PyC layer. The ${ }^{235} \mathrm{U}$ enrichment of the fuel in this configuration of HTR-10 was 17 wt.\%. 
The IRPhEP handbook provides an experimental eigenvalue along with the corresponding experimental uncertainty for the first critical state of HTR-10.

SCALE/KENO-VI models of HTR-10 developed for earlier Oak Ridge National Laboratory (ORNL) studies (Sunny and Ilas, 2010; Ilas et al., 2012) will be used for the computational analyses in Phase 4. A comparison of calculated eigenvalues based on recent ENDF/B nuclear data libraries with the measured value and a first assessment of the impact of nuclear data uncertainties on the eigenvalue uncertainty for HTR-10 were documented in an earlier ORNL study (Bostelmann et al., 2020b).

Table 3. Key characteristics of the initial critical configuration of the HTR-10 (Terry et al., 2007).

\begin{tabular}{|l|r|}
\hline Reactor power (MWth) & 10 \\
\hline Coolant & Ambient air \\
\hline Number of pebbles in the core & 9,627 \\
$\quad$ Fuel pebbles & 7,263 \\
$\quad$ Dummy pebbles & $61 \%$ \\
\hline Pebble packing fraction & 10.4 \\
\hline $\mathrm{UO}_{2}$ fuel kernel density $\left(\mathrm{g} / \mathrm{cm}^{3}\right)$ & 17.0 \\
\hline Uranium enrichment $\left(\mathrm{wt} \%^{235} \mathrm{U}\right)$ & 0.25 \\
\hline Fuel kernel radius $(\mathrm{mm})$ & Buffer/PyC/SiC/PyC \\
\hline Fuel particle coating layer materials $(\mathrm{starting}$ from kernel) & $0.09 / 0.04 / 0.035 / 0.04$ \\
\hline Fuel particle coating layer thickness $(\mathrm{mm})$ & $1.1 / 1.9 / 3.18 / 1.9$ \\
\hline Fuel particle coating layer density $\left(\mathrm{g} / \mathrm{cm}^{3}\right)$ & 8,385 \\
\hline Number of particles per fuel pebble & 3.0 \\
\hline Radius of fuel pebble $(\mathrm{cm})$ & 2.5 \\
\hline Radius of fuel zone in pebble $(\mathrm{cm})$ & 1.73 \\
\hline Graphite matrix and fuel pebble outer shell density $\left(\mathrm{g} / \mathrm{cm}^{3}\right)$ & $\sim 1.76$ \\
\hline Graphite density of reflector structures $\left(\mathrm{g} / \mathrm{cm}^{3}\right)$ & $\sim 1.53$ \\
\hline Graphite density of boronated carbon bricks $\left(\mathrm{g} / \mathrm{cm}^{3}\right)$ & 300 \\
\hline Temperature of all materials $(\mathrm{K})$ & \\
\hline
\end{tabular}




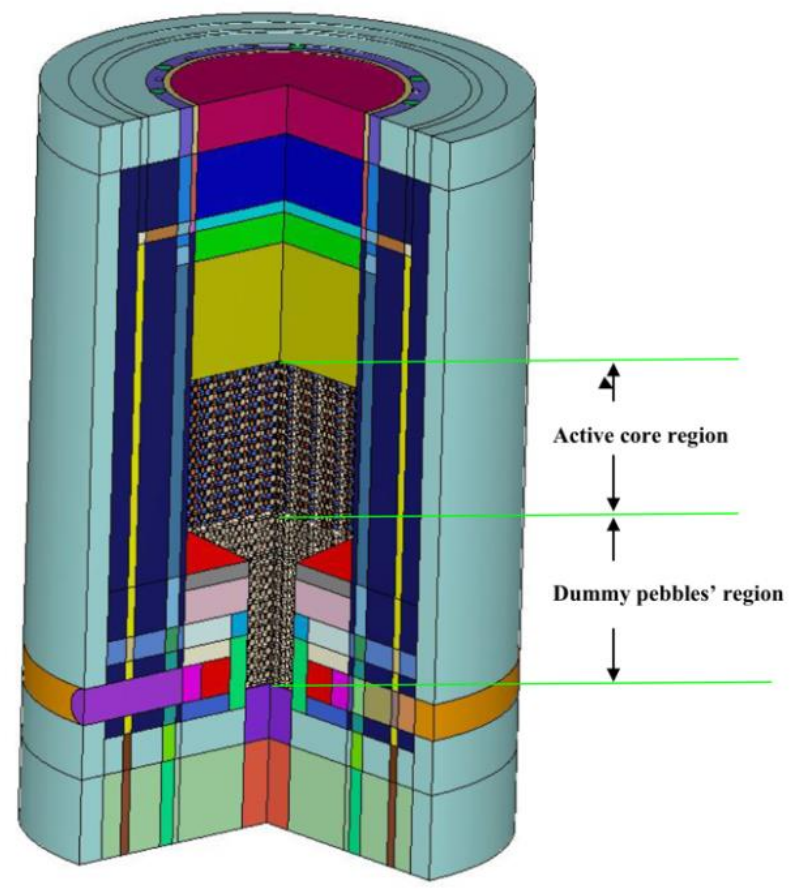

Figure 1. Pebble-bed HTGR model (Ilas et al., 2012).
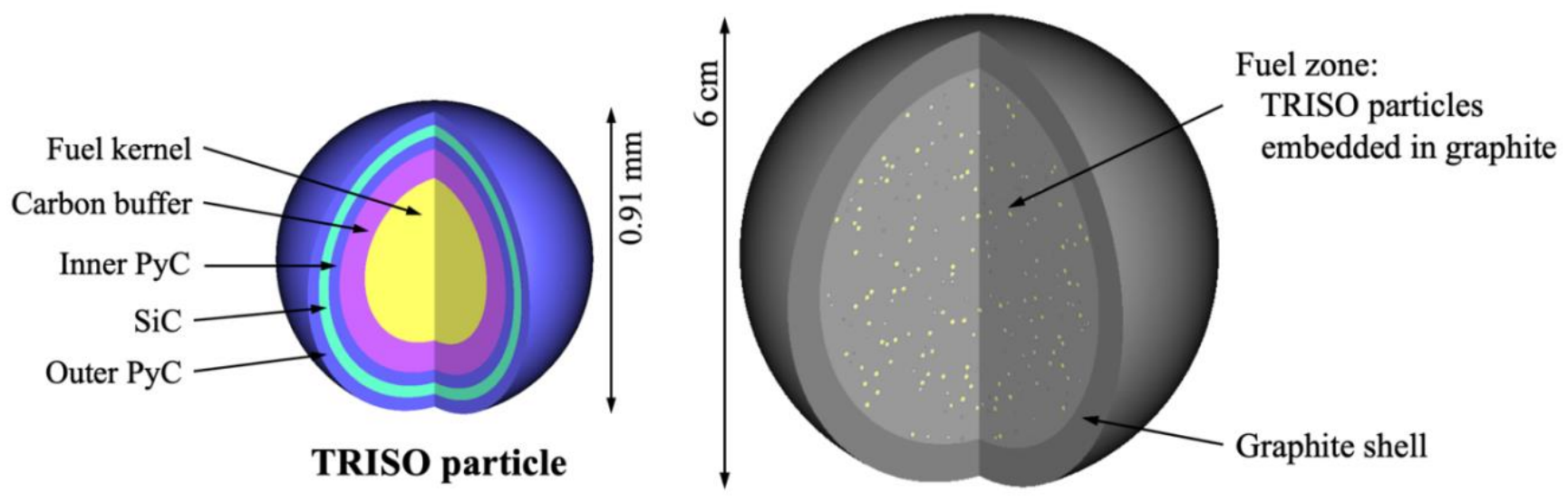

Fuel pebble

Figure 2. Representative TRISO fuel particle and pebble model as included in the HTR-10.

\subsection{PB-FHR-MK1}

The configuration selected for the pebble-bed (PB) fluoride-salt-cooled high-temperature reactor (FHR) technology is the preconceptual design for a small, modular $236 \mathrm{MW}$ th reactor developed by the University of California, Berkeley. The Mark-1 (Mk1) PB-FHR design was developed within the scope of a US Department of Energy project with the goal to establish the technical basis to design, license, and commercially deploy FHRs (Andreades et al., 2014). The key characteristics are presented in Table 4. 
The PB-FHR-Mk1 design combines the HTGR fuel form with liquid fluoride salt coolant in a graphitemoderated environment. The annular core is filled with 470,000 fuel pebbles that are surrounded by 218,000 graphite moderator pebbles, and the core is contained in graphite reflector structures (Figure 3). Like within an HTGR, the fuel pebbles contain TRISO particles distributed in a graphite matrix, in this case an average of 4,730 TRISO particles per pebble, which corresponds to $\sim 1.5 \mathrm{gHM}$ per pebble. However, the fuel pebbles in the FHR are significantly smaller $(3 \mathrm{~cm}$ diameter compared with $6 \mathrm{~cm}$ in, e.g., the HTR-10) and the fuel particles within the FHR pebble are distributed in a shell-like fuel region compared with a spherical fuel region in HTR-10. The fuel region in the FHR pebble is $1.5 \mathrm{~mm}$ thick, and the packing fraction of the TRISO particle in this shell is $40 \%$ (Figure 4).

The fuel material is $\mathrm{UC}_{0.5} \mathrm{O}_{1.5}$ with an enrichment of $19.9 \mathrm{wt} \%{ }^{235} \mathrm{U}$. The coolant salt is FLiBe, a mixture of $\mathrm{Li}_{2} \mathrm{~F}$ and $\mathrm{BeF}$. Core inlet and outlet temperatures are approximately 600 and $700^{\circ} \mathrm{C}$, respectively, and the fuel temperature ranges between 700 and $800^{\circ} \mathrm{C}$. The average thermal power per fuel pebble is $500 \mathrm{~W}$. Burnups reaching up to $180 \mathrm{GWd} / \mathrm{MTHM}$ are intended. Reactivity control is achieved using control rods and blades containing boron carbide (Andreades et al., 2014).

A SCALE model of this reactor is being developed using as a start point an MCNP model published by Cisneros (Cisneros, 2013).

Table 4. Key characteristics of the PB-FHR-Mk1 (Andreades et al., 2014).

\begin{tabular}{|c|c|}
\hline Reactor power (MWth) & 236 \\
\hline Coolant & FLiBe salt \\
\hline $\mathrm{UC}_{0.5} \mathrm{O} 1.5$ fuel kernel density $\left(\mathrm{g} / \mathrm{cm}^{3}\right)$ & 10.5 \\
\hline Uranium enrichment $\left(\mathrm{wt} \%{ }^{235} \mathrm{U}\right)$ & 19.9 \\
\hline Fuel kernel radius $(\mathrm{mm})$ & 0.20 \\
\hline Fuel particle coating layer materials (starting from kernel) & Buffer/PyC/SiC/PyC \\
\hline Fuel particle coating layer thickness (mm) & $0.100 / 0.035 / 0.035 / 0.035$ \\
\hline Number of particles in pebble & 4,730 \\
\hline Particle packing fraction in fuel pebble & $40 \%$ \\
\hline Radius of fuel pebble $(\mathrm{cm})$ & 1.5 \\
\hline Radius of fuel zone in pebble $(\mathrm{cm})$ & \\
\hline Inner & 1.25 \\
\hline Outer & 1.40 \\
\hline Graphite matrix and fuel pebble outer shell density $\left(\mathrm{g} / \mathrm{cm}^{3}\right)$ & 1.73 \\
\hline Graphite density of reflector structures $\left(\mathrm{g} / \mathrm{cm}^{3}\right)$ & $\sim 1.76$ \\
\hline Graphite density of boronated carbon bricks $\left(\mathrm{g} / \mathrm{cm}^{3}\right)$ & $\sim 1.53$ \\
\hline Number of pebbles in the core & \\
\hline Fuel pebbles & 470,000 \\
\hline Dummy pebbles & 218,000 \\
\hline Pebble packing fraction & $60 \%$ \\
\hline Core dimensions $(\mathrm{cm})$ & \\
\hline Inner reflector radius & 35 \\
\hline Outer fuel pebble region & 105 \\
\hline Outer graphite pebble region & 125 \\
\hline Volume of active fuel region $\left(\mathrm{m}^{3}\right)$ & 10.4 \\
\hline Average pebble thermal power (W) & 500 \\
\hline Average pebble discharge burnup (GWd/MTHM) & 180 \\
\hline Average pebble full-power lifetime (years) & 1.40 \\
\hline
\end{tabular}




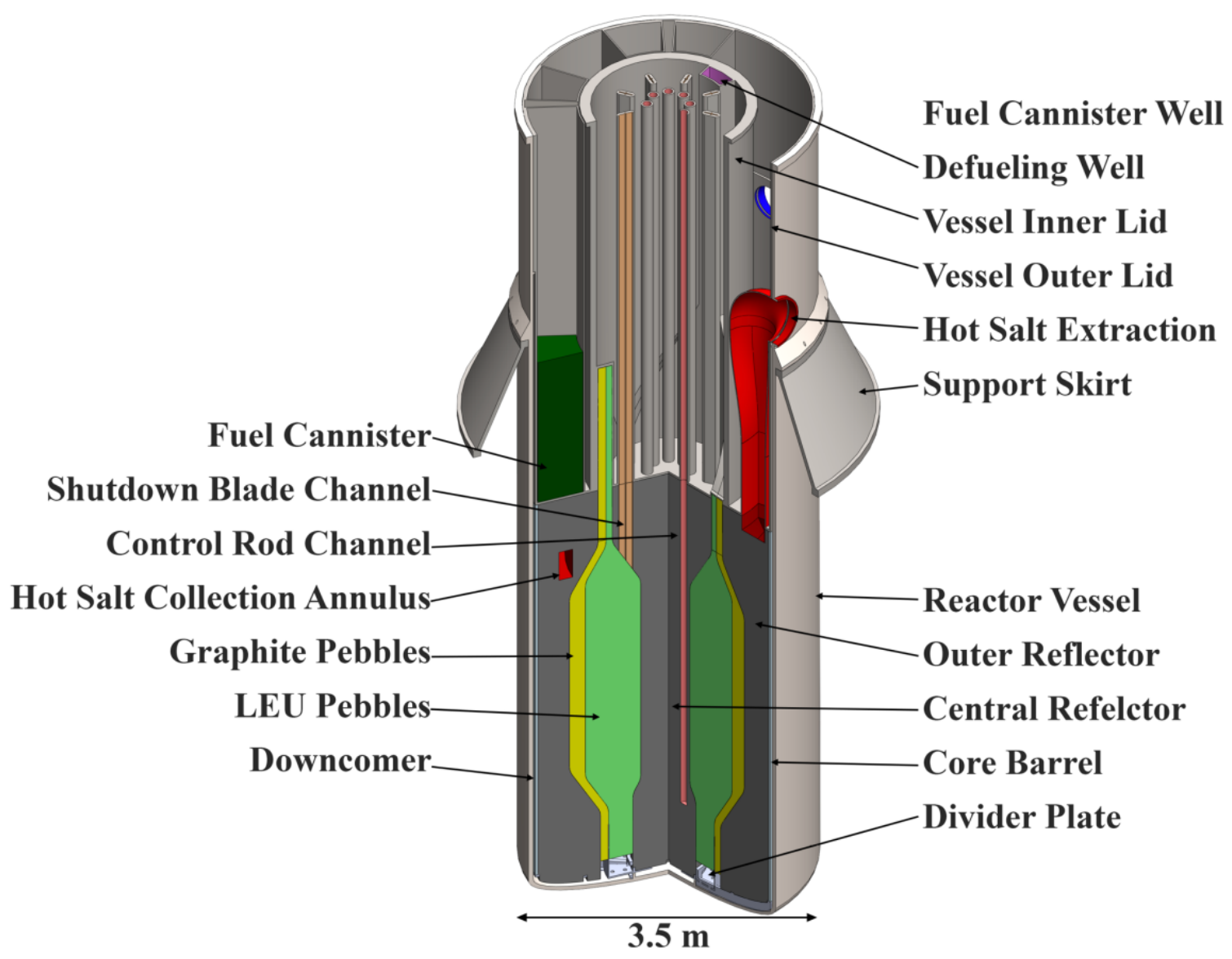

Figure 3. FHR core model (Andreades et al., 2014).

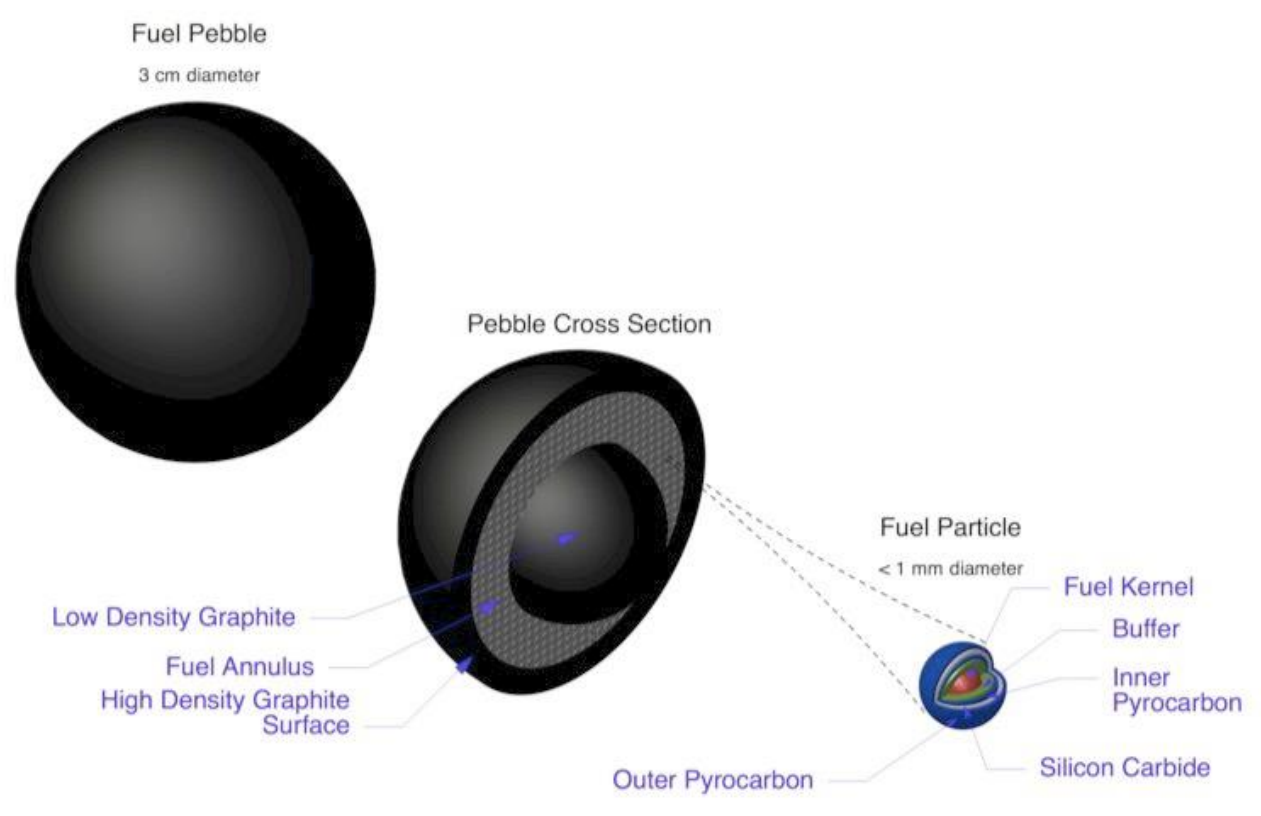

Figure 4. FHR fuel pebble model (Andreades et al., 2014). 


\subsection{MSRE}

The configuration selected for the graphite-moderated molten salt reactor (MSR) is the Molten Salt Reactor Experiment (MSRE). The MSRE was built at ORNL and operated between 1965 and 1969. Its purpose was to demonstrate key features of the molten-salt liquid-fuel reactor concept and to prove the practicality of the MSR technology. This was the first large-scale, long-term, high-temperature testing performed for a fluid fuel salt, graphite moderator, and new nickel-based alloys in a reactor environment. The circulating fuel was a mixture of lithium, beryllium, and zirconium fluoride salts that contained uranium fluorides. Reactor heat was transferred from the fuel salt to a coolant salt and was then dissipated to the atmosphere. The MSRE was designed to provide a thermal output of $10 \mathrm{MW}$ th. The MSRE reached criticality for the first time in June 1965; the corresponding zero-power first critical experiment with ${ }^{235} \mathrm{U}$ was recently included in the IRPhEP handbook (Shen et al., 2019). Table 5 presents an overview of the key characteristics of the MSRE, and Figure 5 and Figure 6 are illustrations of the horizontal and vertical cross sections of the reactor core, respectively.

The MSRE core consisted of a graphite structure within a cylindrical reactor vessel. The fuel salt entered the flow distributor at the top of the vessel through the fuel inlet, was then distributed evenly around the circumference of the vessel, and then flowed downward through a $\sim 2.54 \mathrm{~cm}$ annulus between the vessel wall and the core can. The salt was then pumped upward through the graphite structure. This graphite structure was a lattice of vertical stringers with a side length of $5.08 \mathrm{~cm}$ and an axial length of $170.03 \mathrm{~cm}$. The salt could flow through in more than 1,000 channels, each $\sim 1 \mathrm{~cm}$ thick, that were formed by grooves in the sides on the stringers. In the center of the core, three graphite sample baskets were mounted to allow investigation of the behavior of the graphite moderator in the reactor environment through periodic removals of graphite specimens.

The salt served the dual purpose of carrying the fuel and cooling the core. It was composed of (1) the carrier salt, containing the beryllium, zirconium, and most of the lithium fluorides, (2) depleted uranium eutectic $\left(73 \mathrm{LiF}^{2}-2 \mathrm{UF}_{4}\right)$, and (3) highly enriched uranium eutectic $\left(73 \mathrm{LiF}-27 \mathrm{UF}_{4}\right)$. The reactor vessel consisted of INOR-8, a nickel-based alloy. The core was surrounded by an insulator, simplified in the benchmark specification as a homogeneous mixture $(\mathrm{O}, \mathrm{Fe}, \mathrm{Al}, \mathrm{H}, \mathrm{Si}, \mathrm{Ca})$, and a steel thermal shield.

The temperature specified for the thermal shield and insulation is $305 \mathrm{~K}$; the temperature specified for all other materials in the benchmark is $911 \mathrm{~K}$.

The IRPhEP handbook provides an experimental eigenvalue along with the corresponding experimental uncertainty. The benchmark also provides a calculated eigenvalue obtained with the Serpent code and documents a first assessment of the influence of nuclear data uncertainties on the eigenvalue, as also summarized in a previous conference paper (Shen et al., 2018). 
Table 5. Key characteristics of the MSRE (Shen, 2019).

\begin{tabular}{|c|c|}
\hline Reactor power (MWth) & 10 \\
\hline Fuel and coolant & $\begin{array}{r}64.88 \mathrm{LiF}-29.27 \mathrm{BeF}_{2}-5.06 \mathrm{ZrF}_{4}-0.79 \mathrm{UF}_{4} \\
\text { (expressed as molar percent) }\end{array}$ \\
\hline Fuel salt density $\left(\mathrm{g} / \mathrm{cm}^{3}\right)$ & 2.3275 \\
\hline Graphite density $\left(\mathrm{g} / \mathrm{cm}^{3}\right)$ & 1.8507 \\
\hline Graphite lattice radius $(\mathrm{cm})$ & 70.285 \\
\hline $\begin{array}{c}\text { Core can radius }(\mathrm{cm}) \\
\text { Inner } \\
\text { Outer }\end{array}$ & $\begin{array}{l}71.097 \\
71.737\end{array}$ \\
\hline $\begin{array}{l}\text { Reactor vessel radius }(\mathrm{cm}) \\
\text { Inner } \\
\text { Outer (in active region) }\end{array}$ & $\begin{array}{l}74.299 \\
75.741\end{array}$ \\
\hline Graphite stringer width $(\mathrm{cm})$ & 5.084 \\
\hline Fuel channel width $(\mathrm{cm})$ & 1.018 \\
\hline Fuel channel thickness $(\mathrm{cm})$ & 3.053 \\
\hline Graphite stringer height $(\mathrm{cm})$ & 170.311 \\
\hline Height of the core can $(\mathrm{cm})$ & 174.219 \\
\hline $\begin{array}{l}\text { Total height of the vessel (fr } \\
\text { of vessel to the top of outlet }\end{array}$ & 272.113 \\
\hline
\end{tabular}

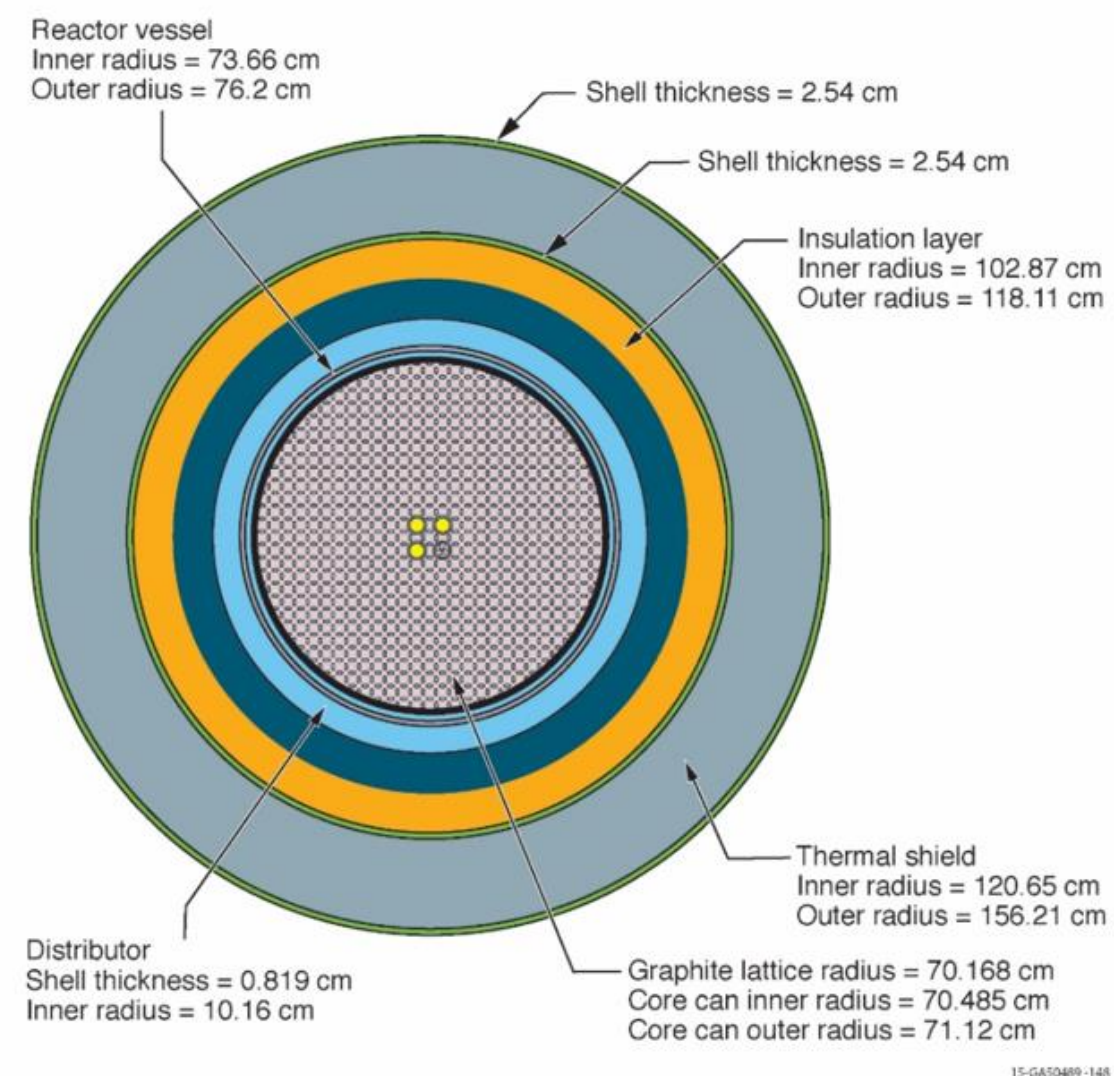

Figure 5. Horizontal cross section of the MSRE benchmark (Shen et al., 2019). Molten salt - light blue; graphite lattice - pink; reactor vessel, INOR (Ni-based alloy) - gray; void - dark blue; insulation, homogeneous mixture (O, $\mathrm{Fe}, \mathrm{Al}, \mathrm{H}, \mathrm{Si}, \mathrm{Ca}$ ) - orange; stainless steel shells - green; mainly steel thermal shield - gray. 


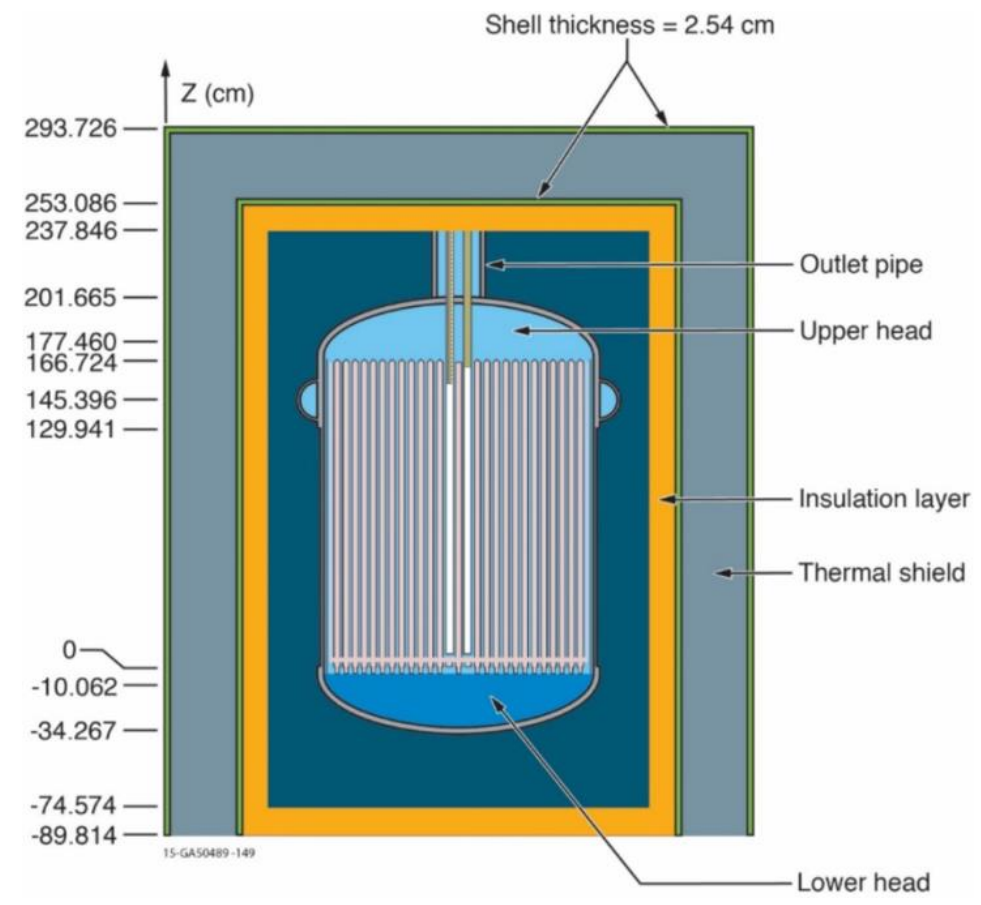

Figure 6. Vertical cross section of the MSRE benchmark (Shen et al., 2019). Molten salt - light blue; graphite lattice - pink; reactor vessel, INOR (Ni-based alloy) - gray; void - dark blue; insulation, homogeneous mixture (O, $\mathrm{Fe}, \mathrm{Al}, \mathrm{H}, \mathrm{Si}, \mathrm{Ca}$ ) - orange; stainless steel shells - green; mainly steel thermal shield - gray;

\subsection{MEGAPOWER}

Heat pipe-cooled reactors with limited power output were first developed at Los Alamos National Laboratory (LANL) during the 1960s. Originally designed for space applications, the Kilopower heat pipe concept was scaled up to the low megawatt electric (MWe) range and is now known as the Megapower reactor (McClure et al., 2015; Figure 7). This concept was further expanded upon by Idaho National Laboratory (INL), and two alternative core designs were proposed (Sterbentz et al., 2018). From these INL designs, Design A was selected for the analysis of heat pipe reactors.

INL Design A includes fuel elements with a solid fuel region and heat pipes containing a potassium (K) coolant. The heat carried away from the core via the heat pipe is converted to power using an open-air Brayton cycle. The core is surrounded with 12 radial control drums and has $\mathrm{Al}_{2} \mathrm{O}_{3}$ and $\mathrm{BeO}$ reflectors on all sides (Figure 8). While the original LANL design (Figure 7) is oriented horizontally, INL Design A is oriented vertically. Design A consists of hexagonal fuel elements that contain a heat pipe (Figure 9). The original INL Design A specifications include $19.75 \%{ }^{235} \mathrm{U}$ enriched $\mathrm{UO}_{2}$. However, in this project, a slightly modified version with metallic fuel consisting of $18.1 \%{ }^{235} \mathrm{U}$ enriched uranium with a $10 \%$ weight fraction of zirconium (U-10Zr) will be studied (Hu, G. et al., 2019). Other key design characteristics are shown in Table 6.

A limited number of neutronics analyses performed with MCNP and Serpent provide calculated values for eigenvalue, reactivities, and reactor power for all concepts (Sterbentz et al., 2018; Lee et al., 2019; Hu, 
G. et al., 2019). However, since the design studied here deviates from the models studied in the referenced reports, only qualitative comparisons can be performed.

Table 6. Key characteristics of the INL Design A (Sterbentz et al., 2018).

\begin{tabular}{|l|c|}
\hline & Design A \\
\hline Reactor power (MWth) & 5 \\
\hline Fuel type & $\mathrm{U}-10 \mathrm{Zr} *$ \\
\hline${ }^{235}$ U enrichment (wt\%) & $18.1^{*}$ \\
\hline Fuel element geometry & 1134 \\
\hline Number of heat pipes & Potassium \\
\hline Heat pipe working fluid & 100 \\
\hline Potassium mass $(\mathrm{g} /$ pipe $)$ & 675 \\
\hline Potassium temperature $\left({ }^{\circ} \mathrm{C}\right)$ & 4 \\
\hline Total heat pipe length $(\mathrm{m})$ & 675 \\
\hline Maximum air temperature $\left({ }^{\circ} \mathrm{C}\right)$ & 1134 \\
\hline Number of fuel elements & 2.78 \\
\hline Fuel pin or element pitch $(\mathrm{cm})$ & 12 \\
\hline Number of control drums & 101.2 \\
\hline Core Diameter $(\mathrm{cm})$ & 4.57 \\
\hline Mass of U in core $(\mathrm{MTU})$ & $904 \mathrm{~kg}$ \\
\hline Mass of ${ }^{235} \mathrm{U}$ in core $(\mathrm{kg})$ & 3.82 \\
\hline Beginning of life excess reactivity $(\$)$ & \\
\hline
\end{tabular}

*Fuel specifications taken from (Hu, G. et al., 2019).

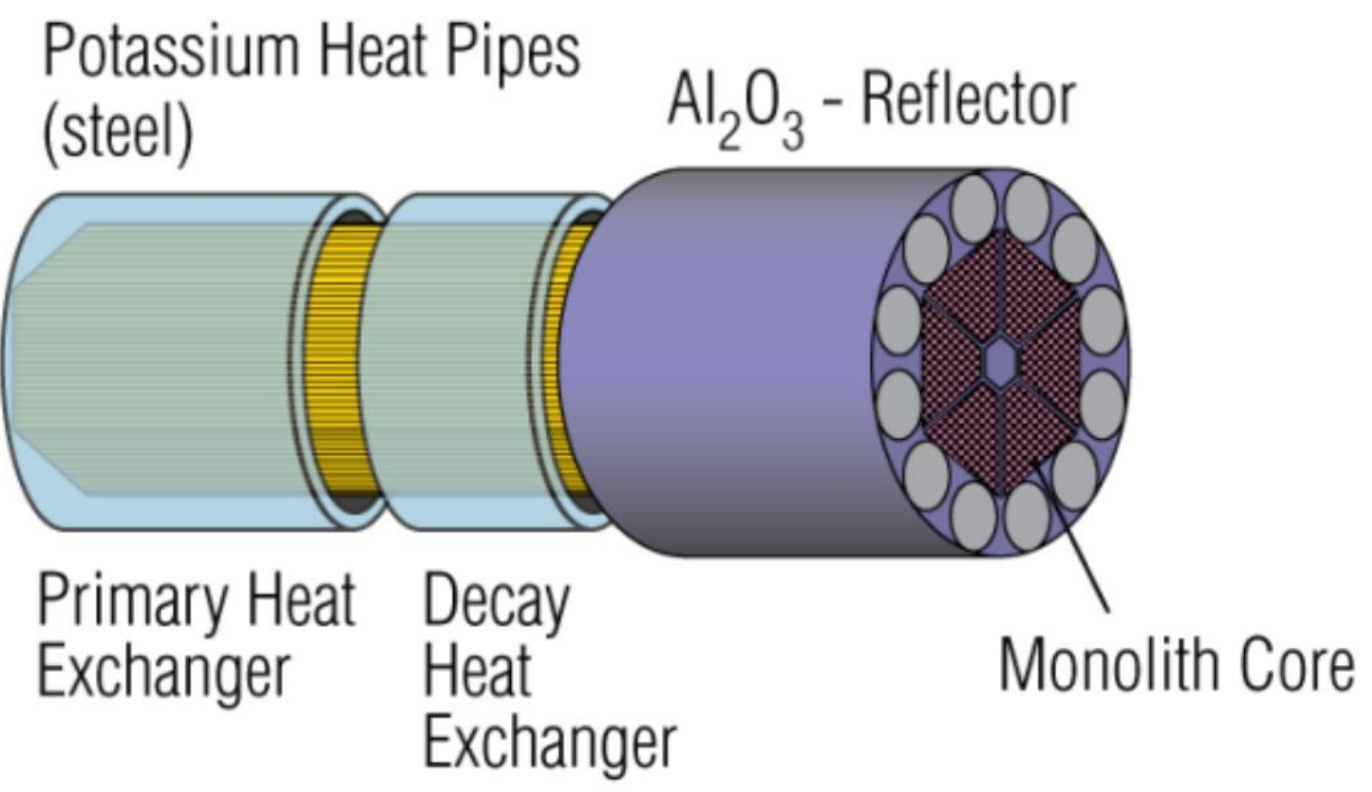

Figure 7. Megapower LANL concept illustration (McClure et al., 2015). 


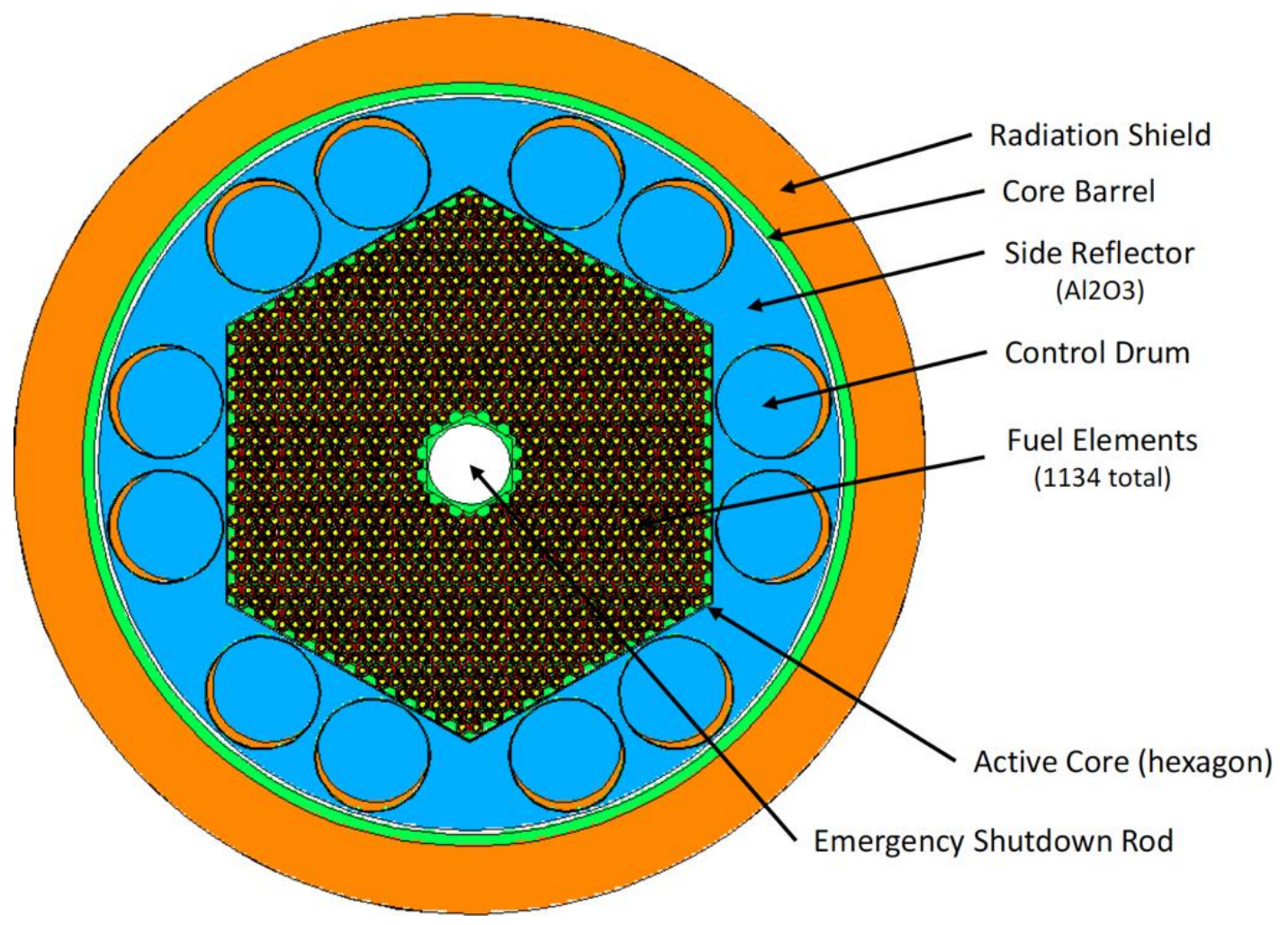

Figure 8. Cross sectional view of INL Design A. (Sterbentz et al., 2018).

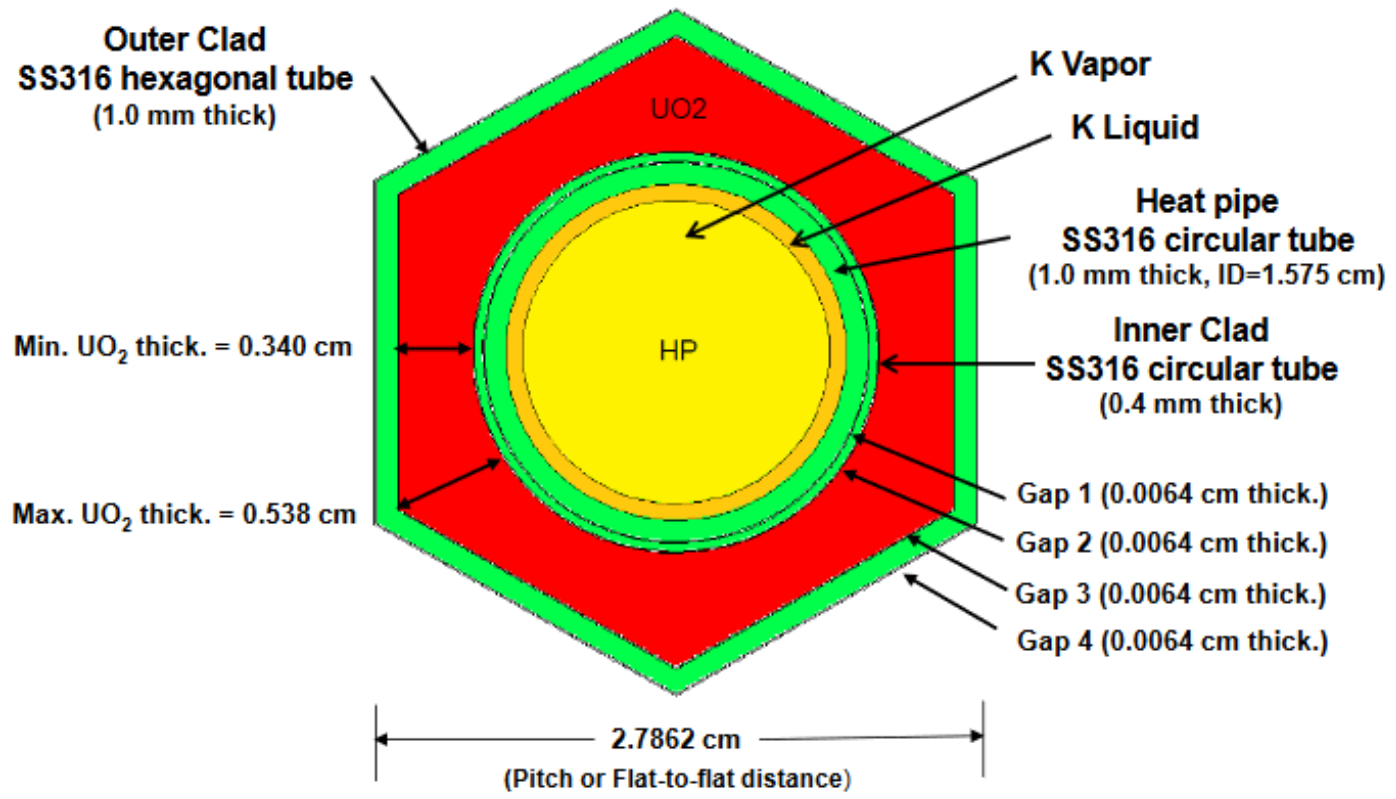

Figure 9. Material composition and dimensions for a INL Design A heat pipe fuel element (Sterbentz et al., 2018). 


\section{$2.5 \quad$ EBR-II}

The benchmark experiment selected for the metal fuel sodium-cooled fast reactor (SFR) technology is the Experimental Breeder Reactor II (EBR-II). EBR-II was operated from 1964 through 1994 by Argonne National Laboratory (on a site which now belongs to INL). It had a maximum heat output of $62.5 \mathrm{MW}$ th. Although initially designed to breed more fuel than it consumed, it was later reconfigured to operate as an irradiation facility where a variety of fuels and structural materials were tested. The evaluation of EBR-II run 138B, a test within the Shutdown Heat Removal Tests series conducted on April 3, 1986, was recently included in the IRPhEP handbook (Lum et al., 2018). Table 7 presents an overview of the key characteristics of this EBR-II benchmark configuration.

The EBR-II core consisted of 637 hexagonal assemblies, divided into three regions: the core, an inner blanket, and an outer blanket (Figure 10). The core region consisted of driver (full worth and half worth) assemblies, experimental/instrumentation assemblies, dummy assemblies, and moveable assemblies used for reactivity control (Figure 11). The safety and control assemblies contained both a fuel and an absorber region. The core was surrounded by an inner blanket of stainless-steel reflector assemblies. The outer blanket region consisted almost entirely of depleted uranium assemblies for breeding and reflection.

The driver fuel assemblies contained a hexagonal lattice of 91 fuel rods. Each fuel rod consisted of enriched uranium metal surrounded by a stainless-steel cladding. Each rod had a wire which wrapped helically up the length of the fuel rod. Due to the complexity of modeling a toroid, the benchmark specifications suggested a single cylinder be modeled, corresponding to the wire wrap. It was also suggested that the region above and below the fuel area - the upper extension, lower extension, and lower adapter - be simplified as homogenized regions of stainless-steel and sodium.

All materials in the EBR-II benchmark are assumed to be at a temperature of $616 \mathrm{~K}$.

The IRPhEP handbook provides an experimental eigenvalue along with the corresponding experimental uncertainty. The results of a criticality calculation based on the benchmark model are also provided. No other calculations of this particular EBR-II benchmark have been found in the open literature.

Table 7. Key characteristics of EBR-II (Lum et al., 2018).

\begin{tabular}{|l|l|l|l|}
\hline Reactor power & $62.5 \mathrm{MW}$ & Assembly pitch & $6.8877 \mathrm{~cm}$ \\
\hline Fuel material & $\begin{array}{l}\text { High enriched } \\
\text { uranium metal }\end{array}$ & Outer fuel radius & $0.1651 \mathrm{~cm}$ \\
\hline Coolant material & sodium & Outer cladding radius & $0.2210 \mathrm{~cm}$ \\
\hline Major structural material & steel & Inner cladding radius & $0.1905 \mathrm{~cm}$ \\
\hline $\begin{array}{l}\text { Temperature of all } \\
\text { materials (K) }\end{array}$ & 616 & Fuel pin pitch & $0.566 \mathrm{~cm}$ \\
\hline $\begin{array}{l}\text { Number of fuel assemblies } \\
\text { in the core: } \\
\quad \begin{array}{c}\text { Full worth } \\
\text { Half worth }\end{array}\end{array}$ & 70 & Active core height & $34.6075 \mathrm{~cm}$ \\
\hline $\begin{array}{l}\text { Number of depleted } \\
\text { uranium blanket assemblies }\end{array}$ & 330 & $\begin{array}{l}\text { Number of fuel pins } \\
\text { per assembly }\end{array}$ & 91 \\
\hline \begin{tabular}{l} 
Major structural material \\
\hline
\end{tabular} & steel & & \\
\hline
\end{tabular}




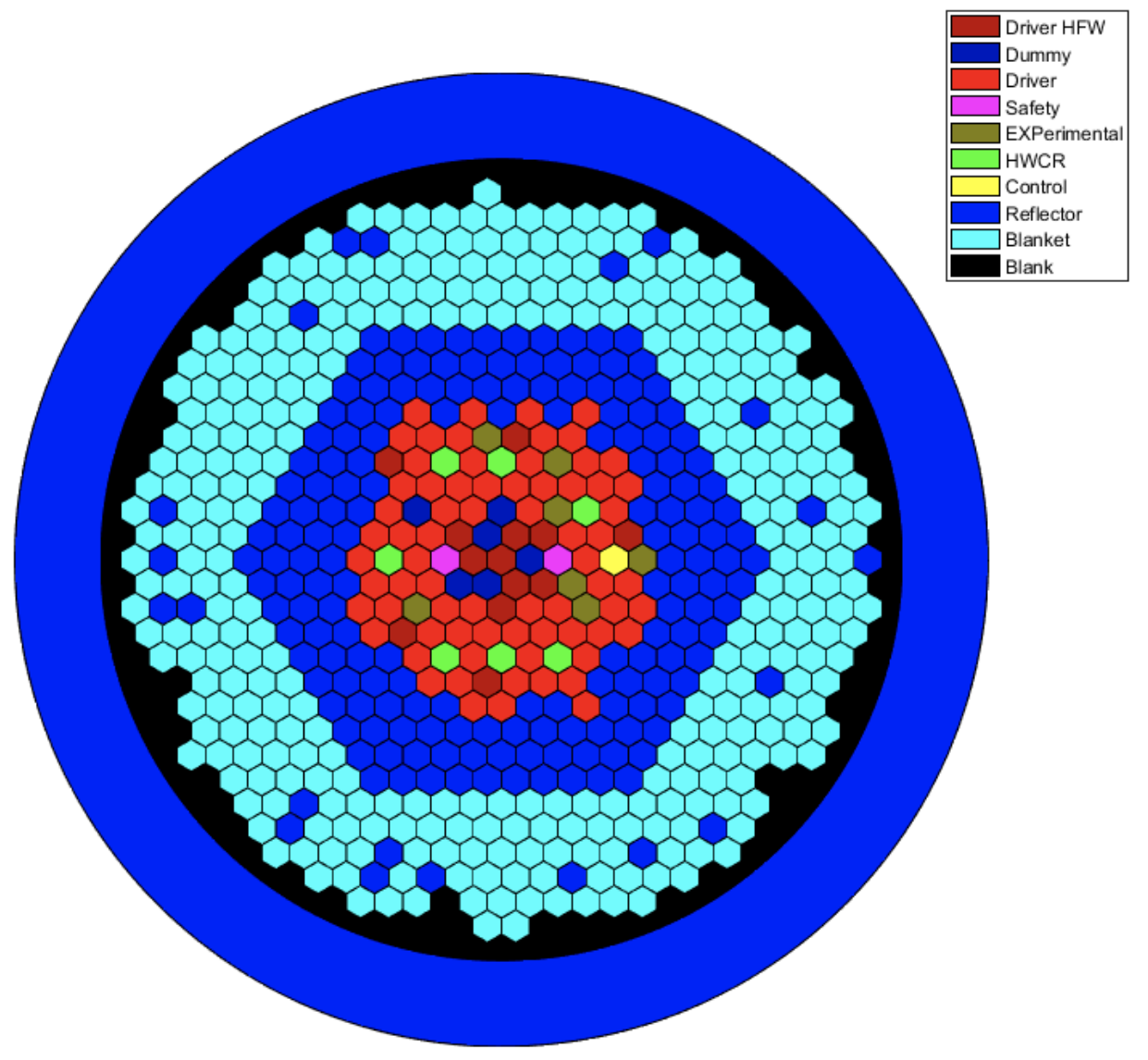

Figure 10. EBR-II Run 138B Core Configuration (Lum et al., 2018). 


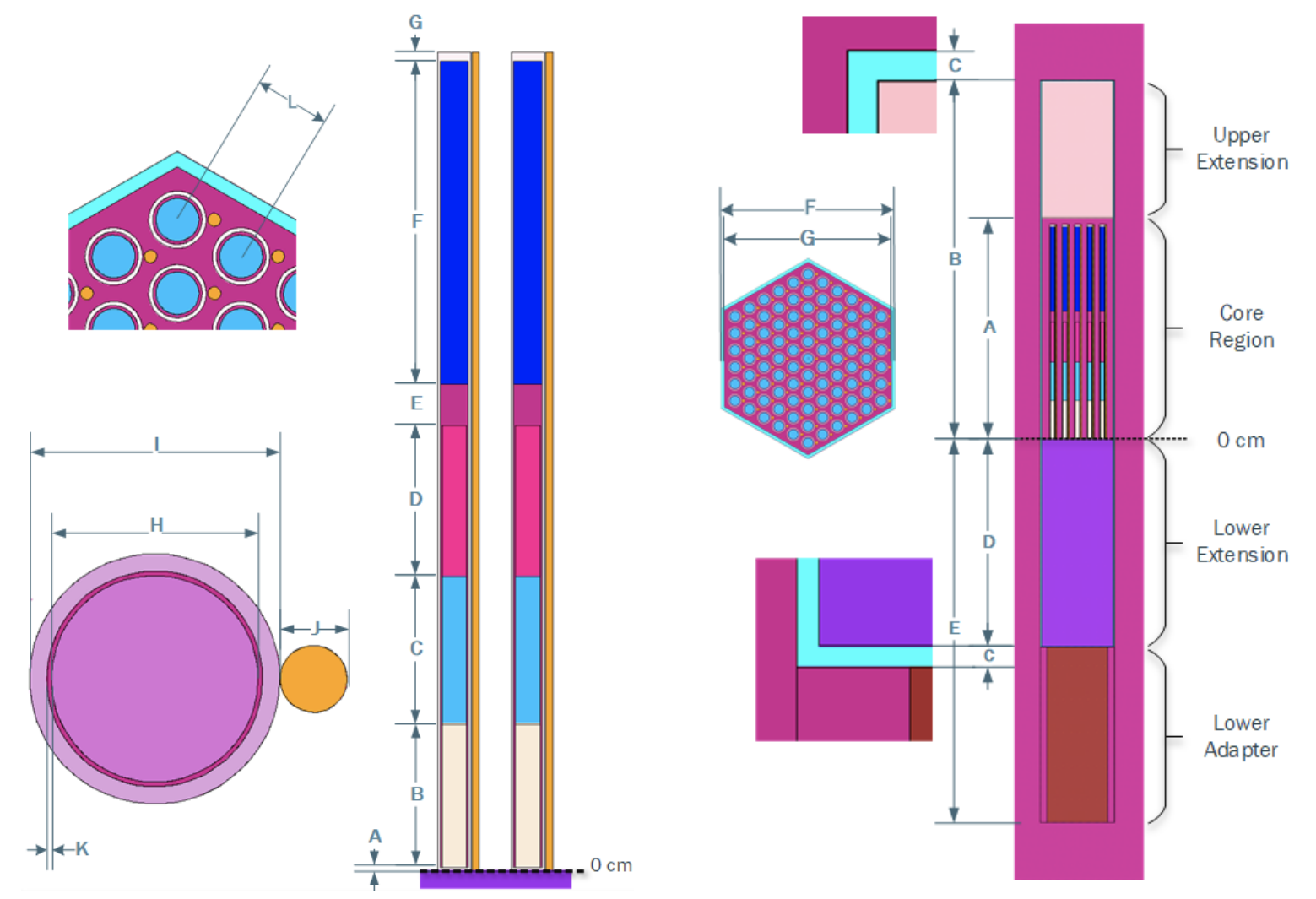

Figure 11. EBR-II driver rod (left) and assembly (right) (Lum et al., 2018). The driver rod consisted of three fuel slugs $(\mathrm{B}, \mathrm{C}, \mathrm{D})$, sodium bond $(\mathrm{E})$ and gas plenum $(\mathrm{F})$.

\subsection{ABR-1000}

The most relevant international activity with respect to nuclear data-related uncertainty analysis of SFRs is the OECD/NEA Benchmark for Uncertainty Analysis in Modeling for Design, Operation and Safety Analysis of SFRs (UAM-SFR) (Buiron et al., 2019). This benchmark is a predecessor of the OECD/NEA Sodium Fast Reactor core Feedback and Transient response (SFR-FT) task force (OECD/NEA, 2016). It was launched in 2015 to study reactivity feedback coefficients and their uncertainties with a mediumsized 1,000 MWth metallic core- a design based on the 1,000 MWth Advanced Burner Reactor (ABR) metallic core (Kim et al., 2009) — and a large 3,600 MWth oxide core. The UAM-SFR benchmark includes full core neutronics and coupled neutronics/thermal-hydraulics calculations and focuses on the analysis of the impact of nuclear data uncertainties on relevant output quantities.

For possible comparison with computational results of various participants, the UAM-SFR benchmark is considered for this project. Given the focus on SFR systems with metallic fuel in the United States, the 1,000 MWth metallic core (ABR1000) was chosen as a second SFR concept besides EBR-II for investigation in this project. The key characteristics of the ABR1000 are presented in Table 8.

The ABR1000 core consists of a grid of hexagonal assemblies (Figure 12). The fuel zone is divided into an inner and outer fuel zone with slightly different fuel compositions. The fuel zone is surrounded by reflector assemblies and an absorbing shield. Reactivity control is maintained by moving control and safety assemblies into locations not occupied by fuel assemblies. The assembly pitch is $16.2471 \mathrm{~cm}$, and the active core height is $85.82 \mathrm{~cm}$. 
The hexagonal fuel assemblies consist of a tight hexagonal lattice of fuel pins surrounded by a HT-9 steel wrapper. From bottom to top, the fuel pins consist of a lower reflector, an active zone with mixed uranium-transuranic-zirconium (U-TRU-Zr) metal alloy fuel, bond sodium (sodium within the fuel rod), and a helium gas plenum always encased in an HT-9 steel cladding (Figure 13). The metal fuel temperature is $534^{\circ} \mathrm{C}$, and the temperature of all structural materials and the coolant is $432.5^{\circ} \mathrm{C}$.

The UAM-SFR benchmark exercise required the calculation of nominal values and uncertainties of

- eigenvalue,

- control rod worth (fully inserted and $5 \mathrm{~cm}$ inserted),

- Doppler constant for fuel temperature increase,

- sodium void worth,

- reactivity changes due to $1 \%$ density changes in the fuel, coolant, cladding, and wrapper (always only in the fuel assembly),

- reactivity change due to $1 \%$ grid expansion while preserving fuel and structural masses,

- reactivity change due to $1 \%$ fuel density change with simultaneous increase of axial fuel length by $1 \%$,

- the axially integrated fuel assembly power (radial power distribution), and

- the axial power distribution of one specified assembly.

A first comparison of calculated nominal values and an assessment of the impact of nuclear data uncertainties on some of the specified quantities were previously published (Stauff et al., 2017; Bostelmann, 2020c). While the specifications of the UAM-SFR benchmark are only accessible to benchmark participants including ORNL, the ABR1000 concept is described in detail in the publicly accessible SFR-FT task force report (OECD/NEA, 2016). The only difference between the two benchmark specifications is the fuel composition. While the SFR-FT task force model included beginning-of-equilibrium-cycle (BOEC) fuel, the UAM-SFR benchmark specifies end-of-equilibriumcycle (EOEC) fuel.

Table 8. Key characteristics of the ABR1000 (OECD/NEA, 2016).

\begin{tabular}{|l|l|l|l|}
\hline Reactor power & $1,000 \mathrm{MWth}$ & Assembly pitch & $16.2471 \mathrm{~cm}$ \\
\hline Fuel material & U-TRU-Zr metal alloy & Outer fuel radius & $0.3236 \mathrm{~cm}$ \\
\hline Coolant material & sodium & Outer cladding radius & $0.3857 \mathrm{~cm}$ \\
\hline $\begin{array}{l}\text { Major structural } \\
\text { material }\end{array}$ & HT-9 & Fuel pin pitch & $0.8966 \mathrm{~cm}$ \\
\hline Fuel temperature & $534^{\circ} \mathrm{C}$ & Active core height & $85.82 \mathrm{~cm}$ \\
\hline $\begin{array}{l}\text { Structure and coolant } \\
\text { temperature }\end{array}$ & $432.5^{\circ} \mathrm{C}$ & $\begin{array}{l}\text { Number of fuel } \\
\text { assemblies }\end{array}$ & $\begin{array}{l}180(78 \text { in the inner and } \\
102 \text { in the outer fuel zone })\end{array}$ \\
\hline & $\begin{array}{l}\text { Number of fuel pins } \\
\text { per assembly }\end{array}$ & 271 \\
\hline
\end{tabular}




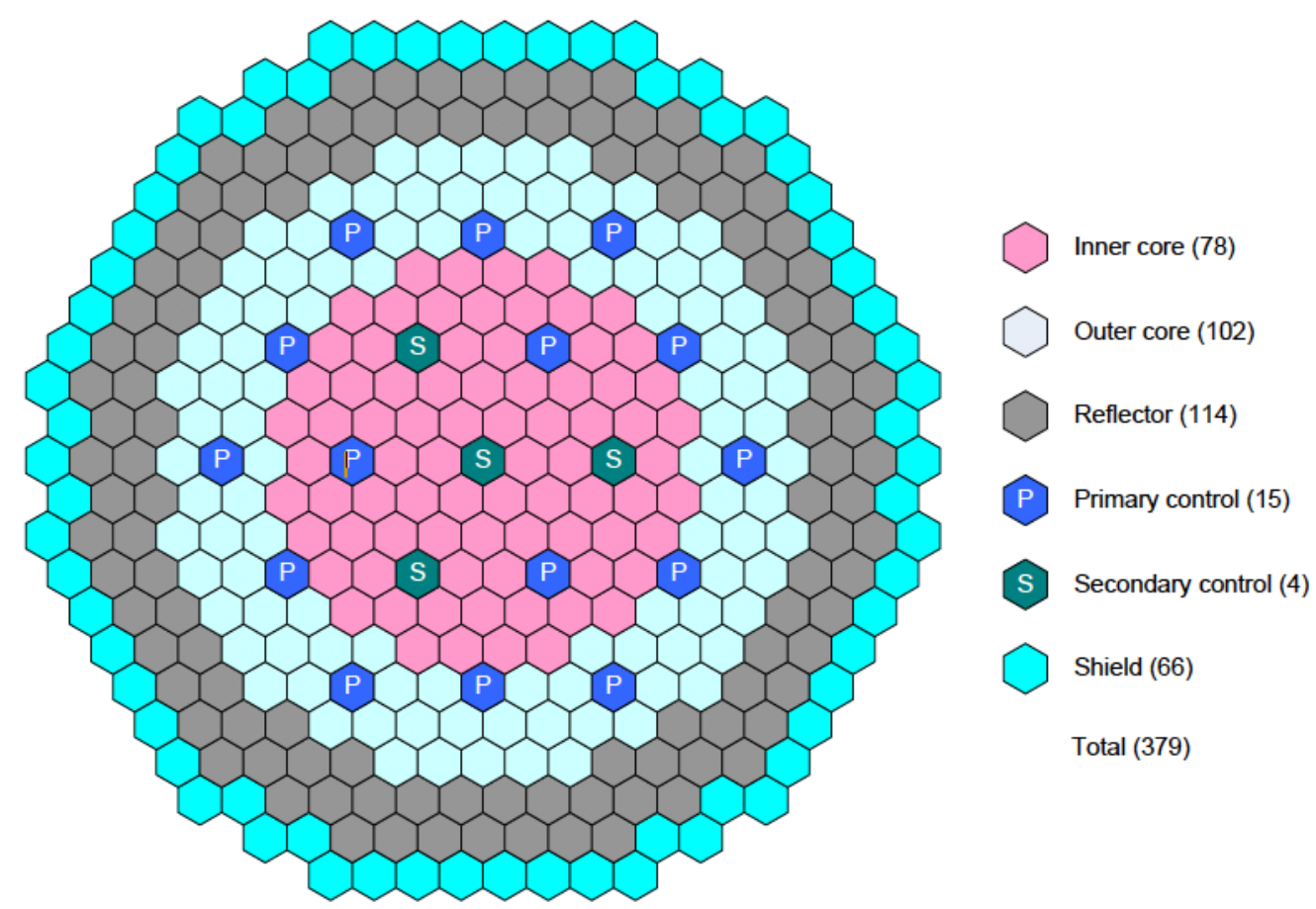

Figure 12. Sodium-cooled fast reactor model cross section view (OECD/NEA, 2016). 


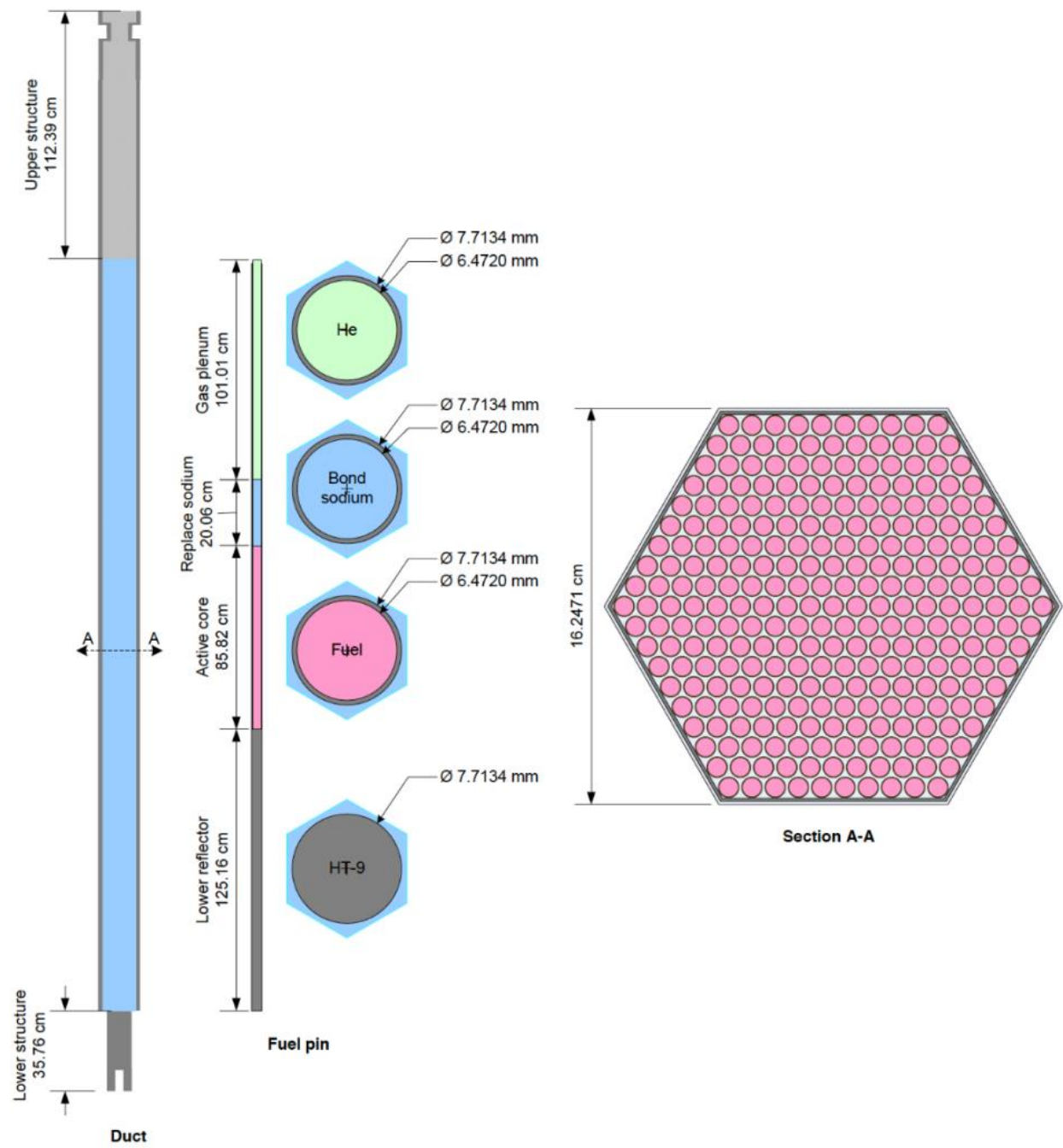

Figure 13. Fuel assembly model of a sodium-cooled fast reactor (OECD/NEA 2016). 


\section{CONCLUSIONS}

The impact of gaps and uncertainties in nuclear data on the reactor physics analysis of selected advanced reactor technologies is investigated in this project. Key nuclear data relevant for reactor safety analysis for each of these technologies were identified in Phase 1, and their impact on important key figures of merit was assessed in Phase 2. In Phase 3, available benchmarks resources were investigated to identify benchmarks suitable for uncertainty analysis calculations planned for Phase 4.

Applicable benchmarks were identified in the OECD/NEA benchmarks documented in the IRPhEP and ICSBEP handbooks. Other benchmarks were selected from ongoing NEA benchmark activities for uncertainty analysis in modeling and from the open literature.

This report provides short descriptions of the selected benchmarks for each of the considered advanced reactor technologies. The IRPhEP HTR-10 benchmark was selected for assessing the effect of nuclear data for the graphite-moderated high-temperature gas-cooled reactor technology. In the absence of experimental benchmarks, the Berkeley PB-FHR Mark 1 concept was selected for the fluoride-cooled high-temperature pebble-bed reactor technology. The MSRE benchmark in IRPhEP was selected for the graphite-moderated molten salt reactor system with circulating fuel salt technology. For the nuclear data assessment for the heat pipe reactor technology, a Megapower concept will be used. The benchmarks selected for the sodium-cooled fast reactor technology are the EBR-II reactor and the theoretical ABR1000 design.

Very limited measured data for advanced reactor systems are available. Relevant benchmarks that provide measured data were identified only for three of the considered advanced reactor technologies (HTR-10, MSRE, and EBR-II). Moreover, even for these selected reactors, only measured eigenvalues and corresponding measured uncertainties are provided. For the fluoride-cooled pebble-bed reactor and the heat pipe reactor technologies, only theoretical concepts were found. Because these models include representative geometric dimensions and representative materials, they are considered applicable for understanding the impact of nuclear data uncertainties and for identifying relevant nuclide reactions in the analysis of safety metrics of interest.

\section{ACKNOWLEDGMENTS}

Support for this work was provided by the US Nuclear Regulatory Commission (NRC). 


\section{REFERENCES}

Andreades, A., et al., 2014. Technical Description of the Mark 1 Pebble-Bed Fluoride-Salt-Cooled HighTemperature Reactor (PB-FHR) Power Plant, University of California, Berkeley, UCBTH-14-002.

Bostelmann, F., et al., 2020a. Key Nuclear Data Impacting Reactivity in Advanced Reactors, ORNL/TM2020-1557, Oak Ridge National Laboratory, Oak Ridge, TN.

Bostelmann, F., et al., 2020b. "SCALE capabilities for high temperature gas-cooled reactor analysis," Annals of Nuclear Energy 147, 107673.

Bostelmann, F., 2020c. Systematic Uncertainty and Sensitivity Analysis of Sodium-Cooled Fast Reactor Systems, PhD Thesis, EPFL.

Buiron, L., et al., 2019. "Benchmark for Uncertainty Analysis in Modelling (UAM) for design, operation and safety analysis of SFRs," OECD/NEA, Version 1.6, 2019. Distribution limited to benchmark participants.

Cisneros, A. T., 2013. Pebble Bed Reactors Design Optimization Methods and their Application to the Pebble Bed Fluoride Salt Cooled High Temperature Reactor (PB-FHR), PhD Thesis, UC Berkeley.

Hu, G., et al., 2019. "Multi-Physics Simulations of Heat Pipe Micro Reactor, ANL-NSE-19/25," Argonne National Laboratory, Lemont, IL.

Ilas, G., et al., 2012. Validation of SCALE for High Temperature Gas-Cooled Reactor Analysis, NUREG/CR-7107, US Nuclear Regulatory Commission.

McClure, P., et al., 2015. "Design of Megawatt Power Level Heat Pipe Reactors," Los Alamos National Laboratory, LA-UR-15-28840.

Kim, T., et al., 2009. "Core design studies for a 1000MWth Advanced Burner Reactor," Annals of Nuclear Energy, 36(3), pp. 331-336.

Lee, C., et al., 2019. "Micro Reactor Simulation Using the PROTEUS Suite in FY19," ANL/NSE-19/33, Argonne National Laboratory, Lemont, IL.

Lum, E. S., et al., 2018. "Evaluation of Run 138B at Experimental Breeder Reactor II, a Prototypic Liquid Metal Reactor," International Handbook of Reactor Physics Experiments, EBR2-LMFR-RESR-001, CRIT, NEA/NSC/DOC(2006)1.

OECD/NEA, 2016. Benchmark for Neutronic Analysis of Sodium-Cooled Fast Reactor Cores with Various Fuel Types and Core Sizes, NEA/NSC/R(2015)9.

Shen, D., et al., 2018. "Zero-power criticality benchmark evaluation of the Molten Salt Reactor Experiment," Proc. PHYSOR 2018, Cancun, Mexico, April 22-26.

Shen, D., et al., 2019. "Molten-Salt Reactor Experiment (MSRE) zero-power first critical experiment with ${ }^{235} \mathrm{U}$," International Handbook of Reactor Physics Experiments, MSRE-MSR-EXP-001, NEA/NSC/DOC(2006)1, Rev. 0.

Stauff, N. E., et al., 2017. "Evaluation of the OECD/NEA/SFR-UAM Neutronics Reactivity Feedback and Uncertainty Benchmarks," Proc. International Conference on Fast Reactors and Related Fuel Cycles: Next Generation Nuclear Systems for Sustainable Development (FR17), June 26-29, Yekaterinburg, Russian Federation, IAEA-CN245-149.

Sterbentz, J. W., et al., 2018. Preliminary Assessment of Two Alternative Core Design Concepts for the Special Purpose Reactor, Idaho National Laboratory, Report INL/EXT-17-43212. 
Sunny, E.E., Ilas, G., 2010. "SCALE 6 analysis of HTR-10 pebble-bed reactor for initial critical configuration.” In: CD Proc. PHYSOR 2010 International Conference on Reactor Physics, Pittsburgh, PA.

Terry, W. K., et al., 2007. "Evaluation of the Initial Critical Configuration of the HTR-10 Pebble-Bed Reactor," International Handbook of Reactor Physics Experiments, HTR10-GCR-RESR-001, NEA/NSC/DOC(2006)1, Rev. 0. 